\title{
Phytoextraction of cadmium and lead by three vegetable-crop plants
}

\author{
Syed Yakub Ali, Sambhu Nath Banerjee and Shibani Chaudhury* \\ Department of Environmental Studies, Siksha-Bhavana, Visva-Bharati, Santiniketan 731235, India
}

Article history

Received: 28 June 2016

Accepted: 6 August 2016

Published: 15 August 2016

(c) Ali et al. (2016)

Editor

K K Sabu

Publisher

Horizon e-Publishing Group

Corresponding Author

Shibani Chaudhury

$\bigotimes$ shibani.chaudhury @visvabharati.ac.in

\begin{abstract}
Phytoextraction, is an effective and promising means to cure soil contamination with heavy metals. The present study investigates the ability of three vegetables plants for removal of heavy metals from the contaminated soil and metal mobilization to different plant parts. The three plants selected for the study, Momordica charantia, Vigna unguiculata and Solanum melongena were grown for 90 days in soils artificially contaminated with cadmium (Cd) and lead (Pb) (50mg metal/kg of soil). The concentrations of the two metals were observed to be higher in roots of $M$. charantia and $V$. unguiculata than in soil, but root $\mathrm{Pb}$ level of $S$. melongena was slightly lower than that of soil after 90 days. Translocation potential of the heavy metals indicated higher accumulation of $\mathrm{Cd}$ in roots of $M$. charantia and S. melongena than in leaves while the pattern was completely opposite in $V$. unguiculata. Lead accumulation was higher in roots than in leaves for all the three plant species studied. The Translocation Factor (TF) of $\mathrm{Cd}$ for the three plants was in the range of 1.16 to 2.29 whereas, TF values of $\mathrm{Pb}$ remained $<1$, indicating that only small amount of $\mathrm{Pb}$ was translocated from roots to aerial parts.
\end{abstract}

\section{Keywords}

Heavy metals; Phytoextraction; Chlorophyll content; Translocation factor

Ali, S. Y., S. N. Banerjee and S. Chaudhury. 2016. Phytoextraction of cadmium and lead by three vegetable-crop plants. Plant Science Today 3(3): 298-303. http://dx.doi.org/10.14719/pst.2016.3.3.247

\section{Introduction}

Environmental pollution caused by heavy metals is a growing concern now-a-days due to its ill effects on plants and animals including human beings (John et al., 2008). Various agricultural and industrial activities is on the rise to cope up with the increasing demand of modern civilization, leading to an accumulation of these metals in the water bodies and soil, from which they can easily enter into the food-chain and pose health risks to the human population. Heavy metals are very hazardous pollutants because they are nonbiodegradable, extremely toxic even at low concentrations and can change their mobility under different physico-chemical conditions (Mathew, 2001).
Some heavy metals act as essential elements for animals and plants in trace amounts, such as Cobalt (Co), Copper (Cu), Manganese (Mn), Molybdenum (Mo), Vanadium (V), Nickel (Ni) and Zinc (Zn) (He et al., 2005; Falusi and Olanipekun, 2007). These metals are used for redox processes as components of various enzymes and for regulation of osmotic pressure in cells (Bruins et al., 2000). Other heavy metals such as Cadmium (Cd), Lead $(\mathrm{Pb})$, Chromium (Cr), Mercury (Hg), Aluminum (Al), Gold $(\mathrm{Au})$ and Silver (Ag) have no biological function/beneficial effects (Chang et al., 1996). All these heavy metals may be detrimental to living organisms when present in excess amounts in soil and water bodies. Of all toxic heavy metals, cadmium (Cd) ranks the highest in terms of its 
to cause damage to plant growth and pose serious risk to human health via food chain (Shah and Dubey, 1998).

The levels of Cadmium may rise to be toxic in soils due to mining activities, smelting, fuel combustion, as well as the use of phosphate fertilizers, sewage sludge, batteries, pigments, metal coatings, and plastics (ATSDR, 2011; Goswami and Das, 2015). Lead is another most abundant toxic metal in the earth crust. Presence of excessive amounts of $\mathrm{Cd}$ and $\mathrm{Pb}$ in soils affect various plant processes such as growth reduction, especially root growth, chlorosis, disturbances in mineral nutrition and carbohydrate metabolism, photosynthesis, water absorption, and cause wilting of leaves (Moya et al., 1993, John et al., 2008).

Phytoextraction, an indispensable component of phytoremediation, is widely in use to remove heavy metals from soil by growing selective plants and then harvesting those plants for management the contaminated soil (Jadia and Fulekar, 2009). Both aquatic and terrestrial plants have been used to reclaim contaminated water bodies and soil (Rahmani and Sternberg, 1999; Prasad et al., 2001; John et al., 2008). The ideal plant used for the purpose of phytoextraction should possess the ability to accumulate metal(s) intended to be extracted, preferably in the aboveground parts, tolerate high metal concentrations in soil, grow at an appreciably fast rate to be considered as an agricultural crop (Goswami and Das, 2015). In the present study, three vegetable-crop plants, Momordica charantia, Vigna unguiculata and Solanum melongena, were studied to estimate their bioaccumulation potential for cadmium and lead present in the artificially contaminated soils and to assess their ability to translocate the metals in shoots and leaves.

\section{Materials and Methods}

Soil sample were collected from field at $20 \mathrm{~cm}$ depth, dried, sieved and was then thoroughly mixed. Various soil parameters such as soil texture, pH, EC, organic Carbon, water soluble sodium, potassium, calcium, exchangeable sodium, potassium, calcium, total nitrogen, water soluble phosphorus, chloride and sulfate, available phosphorus, cation exchange capacity were analyzed. Grain size of the soils was analyzed by 'pipette method'. Soil pH was determined by potentiometric method using $\mathrm{pH}$ meter (Systonic pH-meter 361) in 1:2.5 soil:water suspension. Electrical conductivity was measured in 1:2 soil:water extract using conductivity meter (Thermo Scientic conductivity cell, Orion 013605MD). Organic carbon of the soil was determined by method of Walkely and Black, (1934). Available nitrogen was determined using Kjedahl instrument (PlicanKelplus-Distyl) following the method of Subbiah and Asija, (1956).
Available phosphorus was measured by Bray's method (Bray and Kurtg, 1945). Water soluble anion and cation were determined using Ion Chromatography (Metrohm 797 VA Computrace). For exchangeable sodium, potassium, and calcium, soil samples were extracted by ammonium acetate and the liquid extracts were measured by flame photometry (ELICO CL 361). Cation exchangeable capacity of the soil was determined by following the method of Harada and Inoko, (1980).

After analysis of soil parameters plastic pots with holes at the bottom, were filled with approximately $2 \mathrm{~kg}$ air-dried and sieved soil. The soil was fertilized using $200 \mathrm{gm}$ of cow dung and $5 \mathrm{gm}$ of urea and then artificially contaminated by lead [Lead nitrate, $\mathrm{Pb}\left(\mathrm{NO}_{3}\right)_{2}$ ] and cadmium [Cadmium nitrate, $\mathrm{Cd}\left(\mathrm{NO}_{3}\right)_{2} .4 \mathrm{H}_{2} \mathrm{O}$ ] at $50 \mathrm{mg}$ of each metal/kg of soil following procedures described by Turan and Esringü, (2007). For control pots, similar processes were followed except the addition of metals in the soil. Three edible plant species, Momordica charantia, Vigna unguiculata and Solanum melongena were cultivated in separate pots (in triplicate) in metal contaminated and normal (control) soils. Both the control and metal contaminated pots were watered 3 to 4 times per week. Pot experiments were conducted under ambient climatic conditions from May to August, 2013. The maximum and minimum temperature recorded were $29-34^{\circ} \mathrm{C}$ and the relative humidity ranged from $30-80 \%$. All plant species were harvested after 3 months.

After three months plants were collected from the pots, thoroughly washed in running tap water and rinsed with deionized water to remove each and every soil particle remaining attached with the plant surfaces. Then plant parts (roots, shoots and leaves) were oven dried at $70^{\circ} \mathrm{C}$ for 48 hours. The dried samples were weighed and powdered. For the soil samples, upper most soil portion from the pots were discarded. Then the remaining soils were mixed thoroughly and sieved at $2 \mathrm{~mm}$. Sieved soil samples were collected in the zipper bag for metal analysis.

Soil and dry plant samples (1gm) were digested after adding $15 \mathrm{ml}$ of tri-acid mixture $\left(\mathrm{HNO}_{3}, \mathrm{H}_{2} \mathrm{SO}_{4}\right.$, and $\mathrm{HClO}_{4}$ in 5:1:1 ratio) at $80^{\circ} \mathrm{C}$ until a transparent solution was obtained (Allen et al., 1986). After cooling, the digested sample was filtered using Whatman No. 42 filter paper and the filtrate was finally raised to $50 \mathrm{ml}$ with distilled water. Metals were analyzed by using Anodic Stripping Voltammetry (Metrohm VA 797 Computraces).

The chlorophyll content was determined according to the method of Arnon, (1949). Fresh leaf samples (500mg) were homogenized in $80 \%$ cold acetone and centrifuged at 5000rpm for 15 min (Remi Cooler centrifuge C-4), the absorbance was read at 645nm and $663 \mathrm{~nm}$ (Cyberlab UV-100). Values were expressed as $\mathrm{mg}$ chlorophyll/gm leaves (fresh weight). 
Table 3: Heavy Metals (in ppm) concentration of soil, root, shoot and leaves of three harvested plants

\begin{tabular}{lrrrrrr}
\hline Pt & Cd root & Pb root & Cd shoot & Pb Shoot & Cd leaves & Pb leaves \\
\hline $\begin{array}{l}\text { Momordica } \\
\text { charantia }\end{array}$ & $36.91 \pm 1.87^{\mathrm{a}}$ & $53.72 \pm 1.55^{\mathrm{a}}$ & $22.22 \pm 1.18^{\mathrm{a}}$ & $34.29 \pm 1.53^{\mathrm{a}}$ & $20.63 \pm 1.05^{\mathrm{a}}$ & $2.48 \pm 0.30^{\mathrm{a}}$ \\
\hline $\begin{array}{l}\text { Vigna } \\
\text { unguiculata }\end{array}$ & $29.15 \pm 0.98^{\mathrm{b}}$ & $78.54 \pm 1.83^{\mathrm{b}}$ & $26.35 \pm 0.83^{\mathrm{b}}$ & $4.41 \pm 1.12^{\mathrm{b}}$ & $40.43 \pm 1.52^{\mathrm{b}}$ & $7.06 \pm 0.61^{\mathrm{b}}$ \\
\hline $\begin{array}{l}\text { Solanum } \\
\text { melongena }\end{array}$ & $28.48 \pm 1.72^{\mathrm{ab}}$ & $41.99 \pm 1.57^{\mathrm{c}}$ & $24.97 \pm 1.53^{\mathrm{bc}}$ & $10.87 \pm 1.47^{\mathrm{c}}$ & $11.90 \pm 1.63^{\mathrm{ab}}$ & $6.33 \pm 0.58^{\mathrm{ab}}$ \\
\hline
\end{tabular}

The same letter within columns are not significantly different at the $5 \%$ probability level by least significant range.

Table 4: BCF and TF value of harvested plants

\begin{tabular}{lcccc}
\hline & \multicolumn{2}{c}{ Bioconcentration factors } & \multicolumn{2}{c}{ Translocation factors } \\
\hline & $\mathrm{Cd}$ & $\mathrm{Pb}$ & $\mathrm{Cd}$ & $\mathrm{Pb}$ \\
Momordica charantia & $1.60 \pm 0.04$ & $1.29 \pm 0.04$ & $1.16 \pm 0.03$ & $0.68 \pm 0.005$ \\
Vigna unguiculata & $1.92 \pm 0.01$ & $1.29 \pm 0.03$ & $2.29 \pm 0.04$ & $0.15 \pm 0.03$ \\
Solanum melongena & $1.31 \pm 0.03$ & $0.85 \pm 0.04$ & $1.29 \pm 0.07$ & $0.41 \pm 0.05$ \\
\hline
\end{tabular}

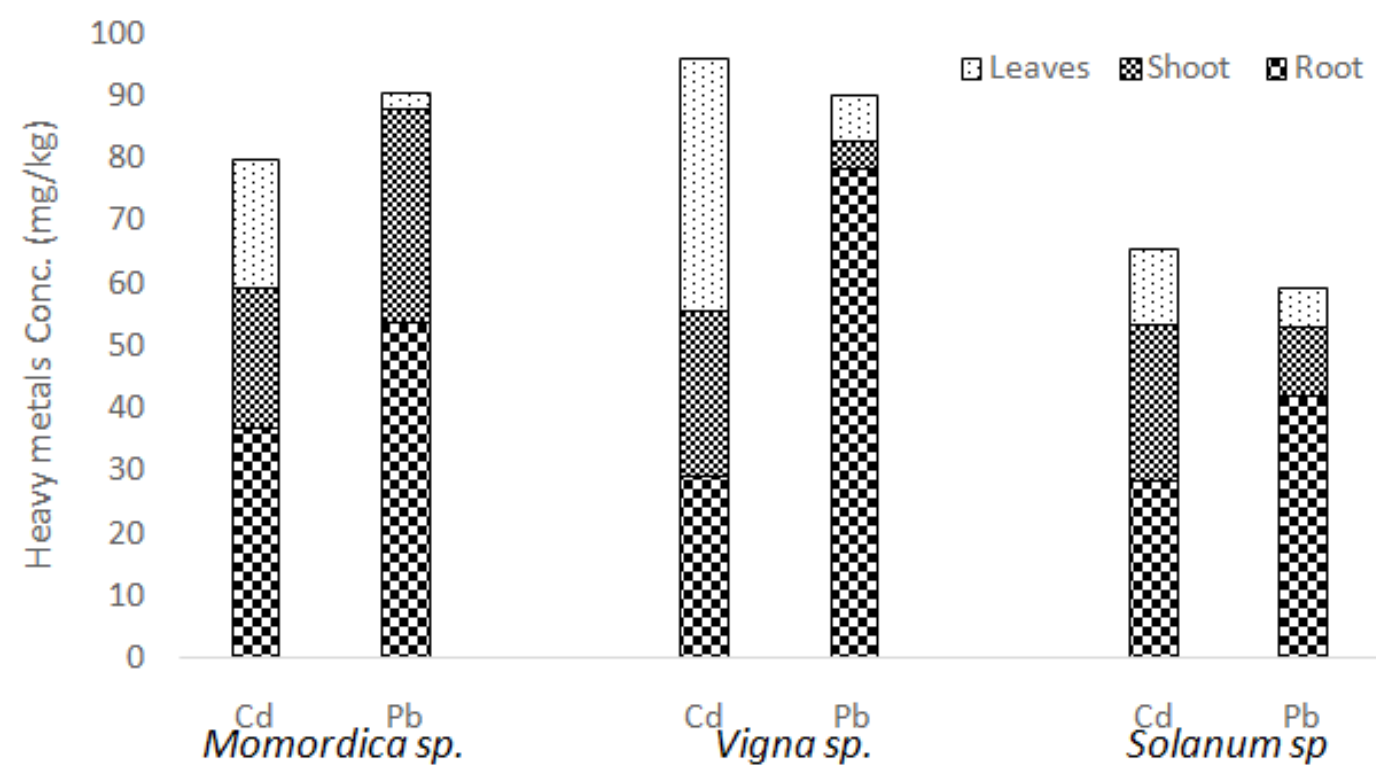

Fig. 1: $\mathrm{Cd}$ and $\mathrm{Pb}$ concentration in roots, shoots and leaves of three harvested plants

The results were statistically analyzed with the help of Microsoft Excel 2013 using one way ANOVA to determine the degree of significance for the studied plants.

\section{Results and Discussion}

The physico-chemical characteristics of uncontaminated soil samples are listed in Table 1. The three plant species were found to grow well in the heavy metal contaminated soils. There were neither any visible change in the morphology of the plants under the influence of metal stress as compared to control plants nor any sign of chlorosis in the treated plants (Table 2). Earlier observers (Unni et al., 1992; Kopittke et al., 2007; Siddhu et al., 2008; Daniel et al., 2009; Yilmaz et al.,
2009; Gautam et al., 2014) have reported such changes as plant growth, germination and peroxidase activity at various doses of $\mathrm{Pb} / \mathrm{Cd}$ applied separately on the same plants. It may be said that combination of these two metals did not alter the morphology of these plants which is well evident in the chlorophyll content of the treated and control plants. Experiment conducted by AlSubu et al., (1993), on marrow vegetables showed that the toxicity of cadmium and lead was mostly antagonistic and sometimes irregular on the parts of root-treated or foliar-treated plants.

The value of $\mathrm{Cd}$ concentration applied to the soil was higher than the Indian Standard (3 to $6 \mathrm{mg} / \mathrm{kg}$ ) but the $\mathrm{Pb}$ concentration was much lower than the tolerable limits (250 to $300 \mathrm{mg} / \mathrm{kg}$ ) as stated by Kabata-Pendias, (2001). 
Table 1: Physio-chemical characteristics of uncontaminated soil

\begin{tabular}{ll}
\hline Parameters & Quantity \\
\hline Soil type & Sandy Loam \\
pH & 6.3 \\
Electron Conductivity & $1 \mathrm{mS} / \mathrm{cm}$ \\
Organic Carbon & $1.1 \%$ \\
Water soluble Cations: & \\
Sodium & $46.9 \mathrm{mg} / \mathrm{kg}$ \\
Potassium & $60.4 \mathrm{mg} / \mathrm{kg}$ \\
Calcium & $31.7 \mathrm{mg} / \mathrm{kg}$ \\
Exchangeable Cations: & \\
Sodium & $213.2 \mathrm{mg} / \mathrm{kg}$ \\
Potassium & $17.1 \mathrm{mg} / \mathrm{kg}$ \\
Calcium & $1537 \mathrm{mg} / \mathrm{kg}$ \\
Water Soluble Anions: & \\
Chloride & $350 \mathrm{mg} / \mathrm{kg}$ \\
Phosphorus & $0.56 \mathrm{mg} / \mathrm{kg}$ \\
Sulfate & $48 \mathrm{mg} / \mathrm{kg}$ \\
Total Nitrogen & $209 \mathrm{mg} / \mathrm{kg}$ \\
Available Phosphorus & $2.23 \mathrm{mg} / \mathrm{kg}$ \\
Cation Exchange Capacity & $11.2 \mathrm{meq} / 100 \mathrm{gm}$ \\
Heavy Metals & \\
$\quad$ Zinc & $80 \mathrm{mg} / \mathrm{kg}$ \\
$\quad$ Copper & $55 \mathrm{mg} / \mathrm{kg}$ \\
$\quad$ Lead & $20.5 \mathrm{mg} / \mathrm{kg}$ \\
$\quad$ Cadmium & $\mathrm{ND}$ \\
\hline
\end{tabular}

Table 2: Total Chlorophyll content in control and treated experimented plants

\begin{tabular}{ccc}
\hline \multirow{2}{*}{ Species Name } & \multicolumn{2}{c}{ Total Chlorophyll mg/g } \\
\cline { 2 - 3 } & $\begin{array}{c}\text { Control } \\
\text { Plants }\end{array}$ & $\begin{array}{c}\text { Treated } \\
\text { Plants }\end{array}$ \\
\hline Momordica charantia & 1.23 & 1.18 \\
\hline Vigna unguiculata & 0.46 & 0.42 \\
\hline Solanum melongena & 0.93 & 1.01 \\
\hline
\end{tabular}

Phytoextraction studies showed that the three plant species accumulated higher levels of $\mathrm{Cd}$ and $\mathrm{Pb}$ in their roots, but their ability for translocation of these heavy metals to the aerial plant parts were considerably different. The levels of $\mathrm{Cd}$ were higher in roots of Momordica charantia and Solanum melongena $(36.91 \mathrm{mg} / \mathrm{kg}$ and $28.48 \mathrm{mg} / \mathrm{kg})$ followed by the shoot $(22.22$ $\mathrm{mg} / \mathrm{kg}$ and $24.97 \mathrm{mg} / \mathrm{kg}$ ) and leaves $(20.63 \mathrm{mg} / \mathrm{kg}$, $11.90 \mathrm{mg} / \mathrm{kg}$ ). The trend was opposite in case of Vigna unguiculata which accumulated higher levels of Cd in leaves $(40.43 \mathrm{mg} / \mathrm{kg})$ as compared to root system $(29.15 \mathrm{mg} / \mathrm{kg})$. In case of $\mathrm{Pb}$, the highest accumulation was found to occur in root of all harvested plants. Vigna unguiculata accumulated highest amounts of $\mathrm{Pb}$ in root $(78.54 \mathrm{mg} / \mathrm{kg})$, followed by Momordica charantia
(53.72 $\mathrm{mg} / \mathrm{kg})$ and Solanum melongena $(41.99 \mathrm{mg} / \mathrm{kg})$. In contrast to $\mathrm{Cd}$, translocation of $\mathrm{Pb}$ from root to aerial parts was found to be very poor in Vigna and Solanum with the exception of Momordica which accumulated higher levels of $\mathrm{Pb}$ in shoot $(34.29 \mathrm{mg} / \mathrm{kg})$. Translocation of $\mathrm{Pb}$ from root to the leaves was insignificant in all the three plant species studied (in the range of 2.48 $\mathrm{mg} / \mathrm{kg}$ to $7.06 \mathrm{mg} / \mathrm{kg}$ ).

The accumulation of heavy metals in a plant can be quantified by two factors: the Bioconcentration Factor (BCF) (Eqn. 1) and the Translocation Factor (TF) ((Eqn. 2) (Selamat et al., 2014). The BCF is calculated as the ratio of the element concentration in plant tissues to the concentration of the element in the soil (Zayed $e t$ al., 1998).

\section{Bioconcentration Factor $(\mathrm{BCF})=$ \\ element concentration in plant tissues ........... 1 \\ element concentration in soil}

TF is calculated as the ratio of metal concentrations in aerial part of the plant to those in roots, indicating the ability of the plant to translocate metals from the roots to the shoots (Roongtanakiat, 2009).

Translocation Factor $(\mathrm{TF})=$ $\frac{\text { element concentration in aerial part of the plant }}{\text { element concentration in root these plant }} \quad \ldots 2$

The BCF values of the $\mathrm{Cd}$ and $\mathrm{Pb}$ of all the three harvested plants in the metal contaminated soil were $>1$ except Solanum melongena for $\mathrm{Pb}$. The highest BCF value of $\mathrm{Cd}$ was observed in Vigna unguiculata about 1.92 followed by Momordica charantia and Solanum melongena ranging about 1.60 and 1.29 respectively (Table 4). Furthermore, the $\mathrm{Cd}$ concentrations in the aerial parts of harvested plants were higher than that of the corresponding roots, i.e. the translocation factors (TF) were $>1$. The highest TF values of Cd were observed in Vigna unguiculata, ranging from 2.18 to 2.38 , followed by Solanum melongena ranging from 1.17 to 1.38 and Momordica charantia ranging from 1.1 to 1.23 (Table 4).

From the result observed it is clear that $\mathrm{BCF}$ and TF values of $\mathrm{Pb}$ were less than the values of the $\mathrm{Cd}$. Highest BCF value of $\mathrm{Pb}$ was observed in Momordica charantia and Vigna unguiculata about 1.29 and lowest in Solanum melongena about 0.85 (Table 4). Furthermore, the $\mathrm{Pb}$ concentrations in the aerial parts of harvested plants were lower than that of their roots, i.e. the translocation factors (TF) were $<1$. The TF values of the three harvested plants Momordica charantia, Vigna unguiculata and Solanum melongena were $0.67,0.13$ and 0.41 respectively. 
The present study showed that the distribution of $\mathrm{Cd}$ in the aerial plant parts was found to be significantly higher than roots. The BCF and TF values of $\mathrm{Cd}$ were always $>1$ in all harvested plants. High BCF values indicated that the plants could accumulate $\mathrm{Cd}$ from soil. On the other hand, high TF values indicated that plants could take up Cd from the soil and store it in its above ground parts (Selamat et al., 2014). Highest $\mathrm{BCF}$ and TF values were observed in the Vigna unguiculata, which indicated that this plant was capable of accumulating $\mathrm{Cd}$ to a greater extent from soil than the other two plants and store the metal in the aerial plant parts. Cadmium was stored in the Vigna unguiculata according to following order Leaves $>$ Roots $>$ shoots. Mengel and Kirkby, (1982) stated that Cadmium is readily transported from the soil to the upper parts of plants. Transport of $\mathrm{Cd}$ from the soil to plant parts of agricultural crops is significantly greater than other heavy metals except Zinc (Moolenar ad Lexmond, 1999).

$\mathrm{TF}$ values of $\mathrm{Pb}$ was always $<1$ in all experimental plants, indicating that $\mathrm{Pb}$ concentration in the plant root was always greater than the aerial parts. According to Grill et al., (1985), this may be due to low mobility of $\mathrm{Pb}$, when it is found in low quantities in the soil, given that the root systems prevents the migration of $\mathrm{Pb}$ towards the above ground part of the plant and it only reaches this part if it is found in high concentration.

In the present study phytoextraction and bioaccumulation potential of the three plant species Momordica charantia, Vigna unguiculata and Solanum melongena against $\mathrm{Cd}$ and $\mathrm{Pb}$ were found to be favorable. Translocation of $\mathrm{Cd}$ within the plant system was, however, much higher than that of $\mathrm{Pb}$ for all the three plant species studied. Most of the $\mathrm{Pb}$ extracted from contaminated soil was localized within the root system while a considerable fraction of extracted $\mathrm{Cd}$ was found to be translocated to the aerial parts of the three plant species. Kopittke et al., (2007), obtained similar result while working on Vigna unguiculata. They observed that the tissue concentrations of $\mathrm{Pb}$ were 10 to 50 times greater in the roots than in the shoots, with the critical $\mathrm{Pb}$ concentration being $330 \mu \mathrm{g} / \mathrm{g}$ for the roots and 49 $\mu \mathrm{g} / \mathrm{g}$ for the shoots. Another study reported by Daniel et al., (2009) that the $\mathrm{Cd}^{2+}$ accumulation was greater than $\mathrm{Pb}$ in seeds of bitter-gourd. Qadir et al., (2000) and Chauhan, (2014) observed twofold $\mathrm{Cd}$ accumulation in leafy vegetables as compared to others.

\section{Conclusion}

The results clearly indicate that phytoextraction studies of edible plants are important not only from nutritional point of view, but also from the differential abilities of an individual plant to remove heavy metals from soil and localize them in specific plant parts.

\section{Competing Interest}

The authors declare that they have no competing interests.

\section{Authors' contributions}

All authors have contributed significantly. They have performed the laboratory works and prepared the manuscript.

\section{Acknowledgements}

Reviewers and editor of the article are greatly acknowledged for their tremendous effort in reviewing the manuscript. A special mention is important for Mr. Bikash Chakroborty and Mrs. Rani Kisku who helped to maintain the plants.

\section{References}

Allen, S. E., H. M. Grimshaw, and A. P. Rowland. 1986. Chemical analysis. In: Methods in Plant Ecology. P.D. Moore and S. B. Chapman, Ed. Blackwell, Scientific Publication, Oxford, London. p. 285-344.

Al-Subu, M. M., R. Salim, A. Douleh, and A. Atallah. 1993. Combined Effects of Cadmium, Lead and Copper on the growth and on metal uptake of Broad Beans, Carrots, Radishes and Marrow vegetables, Rev. Int. Contam. Ambient 9: 1-9.

Arnon, D.I. 1949. Copper enzymes in isolated chloroplast: Polyphenoloxidase in Beta vulgaris. Plant Physiol 24: 1-15.

ATSDR, 2011. CERCLA Priority List of Hazardous Substances, Agency for Toxic Substances and Disease Control (Online), available URL: http://www.atsdr.cdc.gov/spl/index.html (accessed on 2nd October 2012).

Bray, R. H., and L. T. Kurtg. 1945. Determination of total, organic and available forms of phosphorus in soil. Soil Sci 59: 39-45.

Bruins, M., S. Kapil, and F. Oehme. 2000. Microbial resistance to metals in the environment. Ecotoxicol Environ Saf 45: 198-207. doi: 10.1006/eesa.1999.1860

Chang, L., L. Magos, and T. Suzuki. 1996. Toxicology of Metals. CRC Press, Boca Raton. FL, USA.

Chauhan, G. 2014. Toxicity study of metals contamination on vegetables grown in the vicinity of cement factory. International Journal of Scientific and Research Publication 4: 1-8.

Daniel, G., K. Hussain, and N. Salim. 2009. Bioaccumulation and effect of lead, chromium and cadmium on peroxidase activity in bittergourd (Momordica charantia L. walp) cV. PRIYA. International Journal of Plant Sciences 4: 239-244.

De la Cruz-Landero, N., V. E. Hernandez, E. Guevara, M. A. Lopez-Lopez, A. T. Santos, E. Ojeda-Trejo, and A. Alderete-Chavez. 2010. Lupinus versicolor Response in Soils Contaminated with Heavy Metals from a Petroleum Extraction Field. Journal of Applied Sciences 10: 694-698. doi: 10.3923/jas.2010.694.698

Falusi, B.A., and E. O. Olanipekun. 2007. Bioconcentration Factors of Heavy Metals in Tropical Crab ( Carcinus sp) From River Aponwe, Ado-Ekiti, Nigeria. Journal 
of Applied Sciences and Environmental Management 11: 51-54.

Gautam, M., A. K. Singh, and R. M. Johri. 2014. Influence of $\mathrm{Pb}$ toxicity on yield, yield attributing parameters and photosynthetic pigment of tomato (Solanum lycopersicum) and eggplant (Solanum melongena). Indian Journal of Agricultural Sciences 84: 808-815.

Goswami, S., and S. Das. 2015. A Study on Cadmium Phytoremediation Potential of Indian Mustard, Brassica juncea. International Journal of Phytoremediation 17: 583-588. doi: 10.1080/15226514.2014.935289

Grill, E., E. L. Winnacker, and M. H. Zenk. 1985. Phytochelatins: The principal heavy-metal complexing peptides of higher plants. Sciences 230: 674-676. doi: 10.1126/science.230.4726.674

Harada, Y., and A. Inoko. 1980. The Measurement of the Cation-Exchange Capacity of Composts for the Estimation of the Degree of Maturity. Soil Science and Plant Nutration 26: 127-134.

He, Z., X. Yang, and P. Stoffella. 2005. Trace elements in agroecosystems and impacts on the environment. Journal of Trace Elements and medicine and biology 19: 125-40. doi: 10.1016/j.jtemb.2005.02.010

Jadia, C., and M. Fulekar. 2009. Phytoremediation of heavy metals: Recent techniques. African Journal of Biotechnology 8: 921-928.

John, R., P. Ahmad, K. Gadgil, and S. Sharma. 2008. Effect of cadmium and lead on growth, biochemical parameters and uptake in Lemna polyrrhiza L. Plant Soil and Environment 54: 262-270.

Kabata Pendias A. 2001. Trace Elements in soils and Plants. CRC Press, Boca Raton, FL.

Kamnev, A. A., and D. ven der Lelie. 2000. Chemical and Biological Parameters as Tools to Evaluate and Improve Heavy Metal Phytoremediation. Bioscience Reports 20: 279-258. doi: 10.1023/A:1026436806319

Kopittke, P. M., C. J. Asher, R. A. Kopittke, and N. W. Menzies. 2007. Toxic Effects of $\mathrm{Pb}^{2+}$ on Growth of Cowpea (Vigna unguiculata). Environmental Pollution 150: 280-287. doi: 10.1016/j.envpol.2007.01.011

Mathew, A. R. 2001. Phytoremediation of heavy metal contaminated soil. http://digital.library.okstate.edu/etd/umi-okstate1445.pdf

Mengel, K., and E. Kirkby. 1982. Principles of plant nutrition. International Potash Institute, Switzerland.

Moolenaar, S., and I. Lexmond. 1999. Heavy metal balances. Part 1. General aspects of cadmium, copper, zinc and lead balance studies in agroecosystems. Journal of Industrial Ecology 2: 4-8. doi: 10.1162/jiec.1998.2.4.45

Moya, J. L., R. Ros, and I. Picazo. 1993. Influence of cadmium and nickel on growth, net photosynthesis and carbohydrate distribution in rice plants. Photosynthesis 36: 75-80. doi: 10.1007/BF00016271

Selamat, S. N., R. S. Abdullah, and M. Idris. 2014. Phytoremediation of lead (Pb) and Arsenic (As) by Melastoma malabathricum L. from Contaminated Soil in Separate Exposure. International Journal of Phytoremediation 16: 694-703. doi: 10.1080/15226514.2013.856843

Olsen, S., C. Cole, F. Watanabe, and L. Dean. 1954. Estimation of available phosphorus in soils by extraction with sodium bicarbonate. USDA Circular 939. U.S. Washington D.C., Government Printing Office.

Prasad, M. N. 2003. Phytoremediation of Metal-Polluted Ecosystems: Hype for Commercialization. Russian Journal of Plant Physiology 50: 686-700. doi: 10.1023/A:1025604627496

Prusty, B., K. Sahu, and G. Godgul. 1994. Metal contamination due to mining and milling activities at the Zawar zinc mine, Rajasthan, India. Contamination of stream sediments: Chemical Geology 112: 275-292. doi: 10.1016/00092541(94)90029-9

Qadir, M., A. Ghafoor, and G. Murtaza. 2000. Cadmium concentration in Vegetables grown on Urban soils irrigated with untreated municipal sewage. Environment, Development and Sustainability 2: 1119. doi: 10.1023/A:1010061711331

Rahmani, G. N. H., and S.P. K. Sternberg. 1999. Bioremoval of lead from water using Lemna minor. Bioresource Technology 70: 225-230. doi: 10.1016/S0960-8524(99)00050-4

Roongtanakiat, N. 2009. Vetiver Phytoremediation for Heavy Metal Decontamination. Technical Bulletin no. 2009/1. Pacific Rim Vetiver Network, Office of the Royal Development Projects Board, Bangkok, Thailand.

Shah, K., and R.S. Dubey. 1998. Effect of cadmium on proline accumulation and ribonuclease activity in rice seedlings: Role of proline as a possible enzyme protectant. Biologia Plantarum 40: 121-130. doi: 10.1023/A:1000956803911

Siddhu, G., D. S. Sirohi, K. Kashyap, I. A. Khan, and M. A. A. Khan. 2008. Toxicity of cadmium on the growth and yield of Solanum melongena L. Journal of Environmental Biology 29: 853-857.

Subbiah, B., and Asija, G. 1956. A rapid procedure for the determination of available nitrogen in soil. Current Science 25: 259-260.

Turan, M., and M. T. Esringü. 2007. Phytoremediation based on canola (Brassica napus L.) and Indian mustard (Brassica juncea L.) planted on spiked soil by aliquot amount of $\mathrm{Cd}, \mathrm{Cu}, \mathrm{Pb}$, and $\mathrm{Zn}$. Plant Soil and Environment 53: 7-15.

Unni, P. N., G. Daniel, and S. R. Nair. 1992. Effect of heavy metals on field crops I. effect of lead on germination, growth and chlorophyll content in bitter gourd (Momordica charantia L.). International Journal of Environmental Studies 41: 115-119. doi: 10.1080/00207239208710750

Walkley, A. and I. Black. 1934. An estimation of the Degtjareff method for determining soil organic matter, and a proposed modification of the Chromic acid titration method. Soil Science 34: 2938.

Yilmaz, K., Akinci, I. E., and S. Akinci. 2009. Effect of lead accumulation on growth and mineral composition of eggplant seedlings (Solanum melongena). New Zealand Journal of crop and horticultural Science 37: 189-199. doi: 10.1080/01140670909510264

Zayed, A., S. Gowthaman, and N. Terry. 1998. Phytoaccumulation of trace elements by wetland plants. Journal Environmental Quality 27: 715-721. doi: 10.2134/jeq1998.00472425002700030032x 